IZA DP No. 7419

Employment Verification Mandates and the Labor Market Outcomes of Likely Unauthorized and Native Workers

Catalina Amuedo-Dorantes

Cynthia Bansak

May 2013 


\title{
Employment Verification Mandates and the Labor Market Outcomes of Likely Unauthorized and Native Workers
}

\author{
Catalina Amuedo-Dorantes \\ San Diego State University \\ and IZA \\ Cynthia Bansak \\ St. Lawrence University
}

Discussion Paper No. 7419
May 2013

IZA

P.O. Box 7240

53072 Bonn

Germany

Phone: +49-228-3894-0

Fax: +49-228-3894-180

E-mail: iza@iza.org

Any opinions expressed here are those of the author(s) and not those of IZA. Research published in this series may include views on policy, but the institute itself takes no institutional policy positions. The IZA research network is committed to the IZA Guiding Principles of Research Integrity.

The Institute for the Study of Labor (IZA) in Bonn is a local and virtual international research center and a place of communication between science, politics and business. IZA is an independent nonprofit organization supported by Deutsche Post Foundation. The center is associated with the University of Bonn and offers a stimulating research environment through its international network, workshops and conferences, data service, project support, research visits and doctoral program. IZA engages in (i) original and internationally competitive research in all fields of labor economics, (ii) development of policy concepts, and (iii) dissemination of research results and concepts to the interested public.

IZA Discussion Papers often represent preliminary work and are circulated to encourage discussion. Citation of such a paper should account for its provisional character. A revised version may be available directly from the author. 


\title{
ABSTRACT \\ Employment Verification Mandates and the Labor Market Outcomes of Likely Unauthorized and Native Workers
}

\begin{abstract}
As recent efforts to reform immigration policy at the federal level have failed, states have started to take immigration matters into their own hands and researchers have been paying closer attention to state dynamics surrounding immigration policy. Yet, to this date, there is not a clear understanding of the consequences of enforcing E-verify on likely unauthorized immigrants and on native-born workers across the United States. This study aims to fill in that gap by analyzing the impact that the enactment of various types of E-verify mandates may have on the employment and wages of these two populations. We find that the enactment of both universal and public-sector only mandates reduce employment of likely unauthorized workers. Meanwhile, employment verification does not affect naturalized Hispanic workers but increases the employment likelihood of native workers. Impacts on wages are positive for likely unauthorized women suggesting a large labor supply reduction. For native-born workers, hourly wages also increase and provide some evidence of substitutability of unauthorized immigrants and non-Hispanic natives.
\end{abstract}

JEL Classification: J2, J3, J6

Keywords: E-verify, undocumented workers, employment, wages

Corresponding author:

Catalina Amuedo-Dorantes

Department of Economics

San Diego State University

5500 Campanile Drive

San Diego, CA 92182

USA

E-mail: camuedod@mail.sdsu.edu 


\section{Introduction}

Immigration reform efforts in the United States have traditionally targeted illegal immigration. During the past decades, proposals for a comprehensive immigration reform have increasingly addressed both the supply-side as well as the demand-side of the labor market as a means to curb the number of undocumented immigrants in the country. A prominent argument in the immigration debate has been that, if there were no employment opportunities for undocumented workers, workers would no longer attempt to enter into the United States illegally. Although employers are legally liable for hiring unauthorized workers under the Immigration Reform and Control Act of 1986, some consider IRCA to be a failure as the number of unauthorized immigrants grew by roughly 43 percent between 2000 and 2007. ${ }^{1}$ For instance, it is believed that the vast majority of the estimated 11.2 million unauthorized immigrants that were in the U.S. in 2010 came in search of better employment opportunities and, indeed, their labor force attachment appears to far outweigh that of native-born workers. ${ }^{2}$

As efforts to reform the country’s immigration policy were unsuccessful in both 2006 and 2007 and the Dream Act, which would give legal status to illegal immigrants who came to the United States when they were children, was defeated in Congress in 2010, some states have taken matters into their own hands and started to adopt the employment verification (E-Verify) system as a means to curtail the hiring of undocumented workers. According to the Public Policy Institute of California (PPIC), over 118 laws related to the employment of immigrants

\footnotetext{
${ }^{1}$ Despite intentions to penalize employers for knowingly hiring undocumented immigrants, a key component of IRCA, the sanctions were rarely enforced, and this contributed to the failure of IRCA to stem the flow of unauthorized workers. Furthermore, there were unintended consequences such as wage penalties for likely authorized workers due to possible discrimination by employers immediately following the passage of IRCA (Bansak and Raphael 2001).

${ }^{2}$ According to estimates using the Legalized Population Survey (LPS) -a survey of undocumented immigrants who received amnesty in 1986 - approximately 96 percent of working-age men were employed before being legalized compared to 87 percent of their native-born counterparts (Amuedo-Dorantes and Bansak 2011).
} 
were enacted in 37 states during the 2005-2010 five-year period (Lofstrom, Bohn, and Raphael 2011). The adoption of the E-Verify system - a federally developed identity and work authorization verification system - has been a principal feature in these laws. In addition to passing state-level legislation regarding employment, some states and law enforcement agencies have also passed laws allowing state and local police to ask a person suspected of being in the United States illegally to show proof of documented legal status in the country. ${ }^{3}$ At this point, there is very little statistical evidence regarding the impact of these state-level laws on the potentially unauthorized immigrant population or on native-born workers themselves. In this project, we assess the consequences of state-level E-verify mandates on the employment and wages likely unauthorized, naturalized Hispanics, and non-Hispanic natives. We allow for differences by gender and for whether the measure is universally applied to all firms at the statelevel or only mandated at the public sector.

We find that these mandates do appear to have a chilling effect on the employment of the group considered most likely to be unauthorized. Additionally, the mandates appear to raise the wages of likely unauthorized women. These effects point to labor supply reductions that far exceed any decrease in employers’ demand for likely unauthorized female labor. In contrast, in the case of likely unauthorized men, reductions in labor supply might seem to be matched with

\footnotetext{
${ }^{3}$ A number of states have passed omnibus enforcement bills that forbid state and local officials from avoiding or limiting the enforcement of federal immigration laws. Some examples include Arizona in April 2010 (SB1070), AL HB56 in June 2011, GA HB87 in May 2011, IN SB590 in May 2011, SC S20 in June 2011 and UT's package (H116, H466, H469 and H497) in March 2011. In 2012, additional states have introduced alike omnibus enforcement bills: Kansas (H2576), Mississippi (H488 and S2090), Missouri (S590), Rhode Island (H7313) and West Virginia (S64); even though bills in Mississippi and West Virginia later on failed. Although these laws can have chilling effects, the vast majority have not been implemented by states after being immediately challenged in Court. In this regard, the only clause recently upheld by the Supreme Court in the case of Arizona's SB1070 has been the so-called "show me your papers" clause, which already has some pending discrimination challenges. In addition to these omnibus enforcement bills, up to 64 law enforcement agencies in 24 states have signed 287(g) agreements with the U.S. Immigration and Customs Enforcement (ICE). Section 287(g) of the Illegal Immigration Reform and Immigrant Responsibility Act of 1996 (IIRIRA) allows a state and local law enforcement entity to enter into a partnership with the U.S. Immigration and Customs Enforcement (ICE) in order to receive delegated authority for immigration enforcement within their jurisdiction. Unfortunately, we lack the geographic detail needed to identify the counties.
} 
similar cutbacks in employers' demand for their labor, resulting in unaltered wages. None of these effects are observed among naturalized Hispanics. Finally, E-Verify mandates appear to slightly raise the employment likelihood of non-Hispanic native workers.

In what follows, we discuss employment verification programs and their expected impacts on the labor market outcomes of likely unauthorized workers, naturalized Hispanic workers and non-Hispanic native workers. We then talk about the data and methodology used in our analysis, to conclude with a detailed discussion of the results and some policy recommendations based on our findings.

\section{Background on E-Verify}

E-Verify is an internet-based, free program run by the United States government that compares information from an employee's employment eligibility verify form (I-9) to data from U.S. government records. If the information matches, that employee is considered eligible to work in the United States. If there is a mismatch, E-Verify alerts the employer and the employee is allowed to work while he or she resolves the problem. Specifically, the E-Verify system is designed to prevent the use of fraudulent documents. For example, a social security number must be matched to a valid record in the databases from the Social Security Administration or the Department of Homeland Security.

Eighteen states have enacted laws mandating the use of E-verify by firms with ties to state public programs or by all firms as of 2011 with the objective to reduce employment of unauthorized workers. ${ }^{4}$ Enrollment in E-Verify has jumped since 2005 in line with many of

\footnotetext{
${ }^{4}$ According to the National Conference on State Legislatures (NCSL)), seven states mandate the use of E-Verify by all employers -what we refer to as a "universal" mandate in this study, starting with Arizona (2007), and followed by Mississippi (2008), Utah (2010), NC (2011), TN (2012), South Carolina (2012), Alabama (2012). Eleven states have mandated the use of E-Verify by public contractors, public agencies, or public contract recipients -what we refer to as a "public" mandate in this study. The first states mandating the use of E-Verify exclusively among public
} 
these state mandates. As of October 2010, there were 216,721 employers participating in the system compared to under five 5,000 in 2005, and 13.4 million cases were submitted in FY 2010 according to the U.S. Citizenship and Immigration Services (USCIS, 2011). It is estimated that E-Verify now screens more than 1 in 5 new hires with a disproportionate share verified through larger firms (Rosenblum 2011).

Although the purpose of E-Verify mandates is to reduce unauthorized employment, the mandates may have a number of intended and unintended consequences for both legal and undocumented workers. To date, there has been some evidence by researchers of a decreased probability of employment by likely unauthorized workers in these states and some indications that the reactions by immigrants may vary by gender (Bohn, Lofstrom and Raphael 2010; Amuedo-Dorantes and Bansak 2012).

The news media and others point towards the possibility of a strong 'chilling effect' whereby immigrants may react quickly to state legislation by leaving the state despite the limited enforcement. For example, reports stated that 'Hispanic children vanish from schools' (Associated Press 2011) as Alabama’s law became the strictest state effort to clamp down on illegal immigration. In a similar vein, in a survey conducted by the Georgia Department of Agriculture in December 2011, up to 56 percent of interviewed farmers reported having difficulties in finding workers; similar worker shortages were reported in the restaurant sector, according to a survey carried out by the Georgia Restaurant Association in July 2011 (Immigration Works 2012). Statutes like these reflect lawmakers' efforts to create “attrition through enforcement” and to make life so unbearable for undocumented immigrants that they 'self-deport' and return to their homelands.

employers were Colorado and Idaho in 2006. See Table A in the appendix for a listing of the states with either universal or public E-Verify mandates, as well as the mandates' enactment dates. 


\section{Conceptual Framework and Testable Hypotheses}

Economic theory predicts that the introduction of the E-Verify system will introduce substantial employment costs. According to the U.S. Citizenship and Immigration Services, officials estimate that a mandatory E-Verify program could cost a total of about $\$ 765$ million for fiscal years 2009 through 2012 if only newly hired employees are screened through the program and about $\$ 838$ million over the same 4-year period if both newly hired and current employees are processed (U.S. GAO 2011). Aside from these explicit costs, additional costs of hiring delays are estimated to be 1.6 million individuals per year and lost productivity from letting go unauthorized immigrants could add up to about 14 million work-days (Rosenblum 2011). Therefore, as intended by the mandates (i.e. intended consequences), labor demand for these workers should decrease, resulting in a lower probability of employment and lower wages for the most likely unauthorized. If firms are to replace the lost labor, there might be an increase in demand for authorized labor.

However, there are other complicated dynamics likely at work. As a number of scholars have pointed out, the possibility for unintended consequences are numerous. First, there is the likelihood that fraud would result. No system is foolproof, but this system could be fraught with identity fraud if potential employees use the identities of others (identity theft is a possibility) or if employers collude and misuse the system (Meissner and Rosenblum 2009). For example, false non-confirmations (as a result of employer misuse of the system and because some eligible workers do not have IDs), and false confirmations (identity fraud from use of borrowed or stolen documents) may affect the employment impacts of E-Verify programs. In the case where a mismatch is identified, the employer is required to terminate the worker unless the employee is able to prove that mismatch was erroneous. 
The possibility of use of document fraud and confusion was widespread after the passage of IRCA. With the passage of IRCA, employers were required to complete an Employment Eligibility Verification Form (or I-9) for each new hire certifying the worker's identity and work eligibility. To establish eligibility, new employees could present any of 17 different documents. Specifically, the Specialized Agricultural Workers program (SAW) was believed to be plagued with fraudulent applications. Three to four times as many applications for amnesty were received as the number of farm workers employed, and approximately 85\% were approved (Perotti 1994).

Second, there could be considerable movement across sectors in the labor market. Since the vast majority of states do not have an E-Verify mandate in place or, if they do, it is only mandatory among public employers and contractors (that is, they have what we refer to as a “public" E-Verify mandate herein), there is considerable room for mobility across sectors, states and even between formal and informal employment (Gonzalez 2008). Specifically, individuals could move from the public to the private sector in states with public sector mandates. Workers can move to sectors or firms with exemptions or migrate to a state without an employment verification mandate in place. ${ }^{5}$ Lastly, they can move even further into the shadows by getting 'off-the-books' jobs. If supply-side effects are large enough, wages may rise.

Evidence to date suggests the latter is strong possibility. Likely unauthorized workers might enter the underground economy, trying to avoid encounters with government personnel, and possibly dropping out of the Current Population Survey (CPS) sample. Or, they might move away from areas with strict anti-immigration laws and resettle elsewhere in the United States, typically in a neighboring city, county, or state. While there has not been evidence of 'self-

\footnotetext{
${ }^{5}$ In some states, small firms of less than 10 or, other times, 6 employees are exempt from using E-Verify. Likewise, some states contemplate exemptions for contracts lasting less than 3 months, which is fairly common in agriculture.
} 
deportation', there are anecdotes of students being pulled out of schools in anti-immigrant states. As children leave with their families, it is more likely that there will be a disproportionate impact on unauthorized women compared to men. Immigrant women are more likely to be married and have children. Therefore, they might be particularly concerned about the impact of deportation on family members. If that is the case, women might also be more likely to be the first ones to leave with the children and to do so immediately following the passage of E-verify legislation. Specifically, Alabama’s HB 56 was felt to be disproportionately negative on Latina women who faced the impossible choice to leave the state (Shore 2012). ${ }^{6}$

Third, some previously employed individuals may be 'locked into their job’ and experience discrimination if employers know the mandatory use of the system is only for new hires. Specifically, individuals may be less likely to quit a job and their reduced mobility may expose them to labor market discrimination. Obviously, these outcomes - fraud, labor market churning, and exploitation of existing workers were not the intended consequences of the law. Overall impacts on wages and employment, therefore, will depend on the size of the shifts in the labor demand and supply curves, as well as on the elasticities of these functions.

\section{Data and Methodology}

\subsection{Data}

For the analysis of the employment likelihood, we rely on monthly data from the Current Population Survey (CPS) spanning from January 2004 to December 2011. Wage-related outcomes are examined using data from the outgoing-rotation group monthly data sets (CPSORG). The CPS provides detailed information on the labor force status, hourly wages, educational attainment, race/ethnicity, and other basic demographics. Nevertheless, it lacks

\footnotetext{
${ }^{6}$ Some even go as far as considering the new legislation a 'war on women', who appear to be disappearing from their families and homes (see: http://restorefairness.org/tag/hb-56/).
} 
sensitive information on individuals' legal status. Therefore, following the literature (see, for instance, Loftstrom et al. 2011), we focus our attention on a group of workers previously shown to be a very good representation of the most likely unauthorized (Passel and Cohn 2010). This group is composed of Hispanic, non-citizen, working age (under 45) individuals with a high school education or less.

Table 1 displays some of the characteristics of the likely unauthorized, naturalized Hispanic and natives in states with and without an E-Verify mandate -the three demographic groups object of analysis. Likely unauthorized workers are rather similar regardless of whether their state of residence has enacted an E-Verify mandate. About 67 percent of them work and earn an average of $\$ 12$ per hour (in 2012 dollars). They are primarily concentrated in the construction industry, followed by food and drink or administrative services. Over half of them are men and approximately 30 years old. Almost 60 percent of them are married and have over one child. Finally, owing to our focus on the likely unauthorized, educational attainment is low. In particular, no more than one third of this sample of individuals with no more than a highschool diploma has completed high-school.

Table 1 also displays the key characteristics of naturalized Hispanics -a sample used as a comparison group to the likely unauthorized. About 72 percent of them are working and their hourly wages hovered around \$14 per hour. As likely unauthorized workers, this group is also primarily concentrated in the construction industry, followed by retail trade and food and drink services. Approximately half of them are men and, on average, 34 years old. Sixty-five percent of them are married and have, on average, one child. However, relative to one third of likely unauthorized immigrants, more than half of naturalized Hispanics with no more than a highschool education have a high-school diploma. 
Finally, we also show some of the key characteristics of a sample of non-Hispanic natives also between the ages of 16 and 45 and with no more than a high-school education. Our intent is to explore how this similarly skilled native sample is impacted, if at all, by the enactment of these types of mandates. As displayed in Table 1, their employment rates are the lowest of the three demographic groups being looked at, with approximately 60 percent of them working. Their hourly wages are, however, similar to those earned by the sample of naturalized Hispanics, i.e. $\$ 14 /$ hour. They are primarily employed in retail trade, followed by construction and food and drink services. Slightly more than half of this sample of less educated natives is male and primarily white. They are 29 years old, on average, and about one third is married. Approximately 67 percent of them have one child and, overall, they display the largest share of high-school graduates of the three samples.

When assessing the size of the treatment group by time period, our cell counts vary based on the outcome under study. For the likely unauthorized sample over the 96 time periods in our study, we have approximately 700 observations on average for the employment outcome in each cell and about 100 individuals who report hourly wages. Turning to our second sample - that of naturalized individuals - we have fewer observations overall which means the cell size by time period for our treatment group is smaller as well and varies from about 120 on average for the employment outcome to only about 20 per cell for wages. Lastly, our native sample is quite large with cell counts over 6,000 for employment and almost 1,000 for wages. Overall, we feel that we have sample sizes that give us reasonable estimates for most of our comparison except for, possibly, wages of naturalized citizens which we interpret with caution. 


\subsection{Methodology}

To evaluate the consequences of employment verification mandates on the employment and wages earned by likely unauthorized workers, we exploit the variation in the enactment of EVerify mandates over time, across sectors, and across states. Specifically, we estimate the following regression:

$$
L_{i s t}=\alpha+\beta_{1} E-\text { Verify_all }_{s t}+\beta_{2} E-\text { Verify }_{-} \text {public }_{s t}+X_{i s t} \gamma+\beta_{3} U_{s t}+\delta_{s}+\phi_{t}+\delta_{s} t+\varepsilon_{i s t}
$$

where: $\varepsilon_{i s t} \sim N\left(\mu, \sigma^{2}\right), i=1 \ldots n$ individuals, $s=$ state, and $t=($ year, month). The dependent variable $L$ stands for the labor market outcome object of interest (i.e. employed, real log hourly wage), E-Verify_all is a dummy equal to 1 if E-Verify was mandated for use by all firms, and $E$ Verify_public is a dummy variable equal to 1 if E-Verify was mandated for public sector firms, public agencies, and/or public contractors. The vector $X$ includes a variety of individual-level characteristics known to impact the examined labor market outcomes, such as gender (when men and women are pooled together), race, age, marital status, number of children, and educational attainment. Additionally, industry fixed-effects are included in the wage regressions. Finally, we include a battery of state fixed-effects $\left(\delta_{s}\right)$, time (i.e. (year, month)) fixed-effects $\left(\phi_{t}\right)$, monthly state unemployment rates $\left(U_{s t}\right)$ and state-level time trends $\left(\delta_{s} t\right)$ intended to capture idiosyncratic state-level characteristics, economy-wide shocks and time-varying economic conditions at the state level, such as drastic increases in the shares of likely unauthorized migrants, higher unemployment rates placing downward pressure in the labor market of natives or changes in the political atmosphere of the state.

Equation (1) is estimated for likely unauthorized immigrants, as well as for a comparison sample of similarly skilled naturalized Hispanics. Just as likely unauthorized immigrants, naturalized Hispanics are foreign-born and Hispanic; however, they are legal. Therefore, they 
were not anticipated to be directly impacted by state-level legislation aimed at reducing the hiring of undocumented immigrants. The model is estimated as a linear probability model. Although, in some instances, LPMs can yield predicted probabilities that fall outside the unit circle, they impose fewer restrictions on the distribution of the error term and facilitate convergence when working with small samples (Wooldridge 2008). Standard errors are clustered at the state level.

Finally, we also wish to learn about the impact that E-Verify mandates may have had on similarly aged and skilled non-Hispanic natives. Have they been affected? If similarly skilled natives are good substitutes to likely unauthorized immigrants, their employment and wages may have increased as a result of the opening up of new job opportunities. Alternatively, if both groups of workers do not perform the same types of tasks, we may not see much of an impact or even a decrease in native employment and earnings if likely unauthorized and non-Hispanic native workers of similar skills complement each other.

\section{Labor Market Impacts of E-Verify Mandates}

\subsection{Employment Impacts}

Do public and universal E-Verify mandates reduce the employment of likely unauthorized workers? The figures in Panel A, Table 2 address this question and provide evidence of a statistically and economically significant decline in the employment probability of likely unauthorized workers. Specifically, the enactment of universal mandates appears to reduce the employment likelihood of likely unauthorized workers by approximately 4.6 percentage points. The reduction seems greater among men, for whom the employment likelihood drops by 5.5 percentage points, compared to women who undergo an estimated 2.4 percentage-point reduction following the enactment of such mandates. This is not surprising 
given that a large share of likely unauthorized female workers are employed in the domestic service sector by private households and, therefore, less likely to be impacted by employment verification systems. Furthermore, if there was a big mobility effect and women most negatively impacted by the E-Verify mandate left the state with their families, the employment likelihood of those choosing to stay may not have significantly declined.

We also find evidence of the enactment of employment verification mandates targeting public sector firms, public agencies, and/or public contractors lowering the employment likelihood of likely unauthorized men, although by a smaller 2.6 percentage points. Likely unauthorized men may have been previously hired by companies contracting specific jobs, such as construction works, with the public sector. Hence, employment verification mandates targeting public sector firms, public agencies, and/or public contractors are capable of reducing the employment likelihood of likely unauthorized male workers, despite their smaller scope. However, this type of employment verification mandate does not appear to have a significant impact on the employment likelihood of likely unauthorized female workers.

To serve as a comparison, Panel B in Table 2 displays the estimated employment impacts of the two types of employment verification mandates on working age (under 45) naturalized Hispanics with a high school education or less. Just as likely unauthorized immigrants, naturalized Hispanics are foreign-born and Hispanic. However, they are clearly legal residents and, therefore, were not the target of the employment verification mandates. Overall, unlike we found for likely unauthorized workers, there is no evidence of a statistically significant impact of E-Verify mandates on the employment likelihood of our sample of naturalized Hispanics.

One might also wonder how the enactment of these employment verification mandates impacts native employment. The figures in Panel C, Table 2, address that question. It is worth 
noting, however, that these estimates could be potentially biased if, for instance, states in with higher unemployment rates were more likely to enact this type of measures. To address this potential endogeneity, we incorporate information on state unemployment rates, along with the state/time fixed effects and the state-time trends. Additionally, we double check that the estimated coefficients are not suggestive of the presence of the aforementioned endogeneity. In particular, if states in worse economic conditions were more likely to enact employment verification mandates, we should observe a negative correlation between the enactment of this type of measures and the employment likelihood of native workers. However, the figures in Panel C, Table 2 suggest actually the opposite. The enactment of universal employment verification mandates raises the employment likelihood of both male and female native workers by approximately 2 percentage points. In addition, the enactment of employment verification mandates targeting public sector firms, public agencies, and/or public contractors, which only seem to significantly lower the employment likelihood of likely unauthorized men, seems to only increase the employment likelihood of native male workers by approximately 1.5 percentage points. While we cannot firmly conclude on any ongoing substitutability of likely unauthorized for native labor, the results in Table 2 are highly suggestive of such a pattern.

\subsection{Wage Impacts}

For a deeper understanding of the labor market dynamics driving the employment impacts summarized in Table 2, it is necessary to also look at how E-Verify mandates impact wages. We do so in Table 3. In the case of likely unauthorized workers, wages increase by approximately 6 percent following the enactment of universal mandates. The effect is solely explained by the impact of universal mandates on the wages of likely unauthorized female workers, which rise by approximately 17 percent. 
The fact that, among likely unauthorized men, the employment likelihood decreases and wages stayed unchanged is suggestive of simultaneous reductions in the supply of this labor, possibly due to fear of being identified as unauthorized, as well as in the demand for this type of labor by most employers. While these reductions are also likely to be taking place in the case of likely unauthorized female workers, the fact that their wages increase while their employment decreases hints on potentially larger labor supply reductions among women. What might explain this differential impact by gender? We believe that gender differences in the industrial and occupational distribution of workers are likely to be responsible for such divergences. For instance, if likely unauthorized women are largely employed in domestic services, the demand for their services does not experience as large of a decline as that of their male counterparts more likely to be hired in sectors impacted by the E-Verify mandate, such as construction. As such, the demand for likely unauthorized female labor is likely to drop much less than the one for likely unauthorized male labor, resulting in higher hourly wages for likely unauthorized female workers.

To serve as a comparison group, the figures in Panel B, Table 3, display the impacts that employment verification mandates have on the hourly wages of naturalized Hispanics, ages 1645 with no more than a high-school diploma. The enactment of this type of mandates does not seem to have any significant impact on the wages earned by this demographic group. Hence, among relatively low-skilled and young foreign-born Hispanics, the wage impacts are solely concentrated among those more likely to be unauthorized and are not surprising. There are a number of reasons for not finding any significant wage effects of E-Verify mandates on our comparison groups of women, including offsetting supply responses, differential occupations, and imperfect substitutability among the various groups of female workers being considered. 
Lastly, Panel C in Table 3 displays the wage impacts that the enactment of employment verification mandates may have on the wages earned by natives. In the previous section we noted how the enactment of universal mandates is positively related to a 2 percentage-point higher likelihood of being employed of both male and female natives. According to the figures in Panel C, Table 3, the enactment of universal employment verification mandates is only raising hourly wages among non-Hispanic native men and, in any event, the impact is only marginally statistically significant. Overall, then, universal E-Verify mandates seem to result in higher nonHispanic native employment, if not wages, hinting on potentially similar increases in the supply of and demand for native labor.

In contrast, the enactment of E-Verify mandates targeting public sector firms, public agencies, and/or public contractors increases the employment likelihood of native men by approximately 1.5 percentage points and is associated with hourly wages about 1.9 percent higher than those of native male workers in states without such mandates. These impacts are suggestive of increases in the demand for native labor following the enactment of such a type of mandate.

Overall, the figures in Tables 2 and 3 suggest that employment verification mandates, particularly those with a universal scope, reach their intended purpose of lowering the employment of male and female likely unauthorized workers. However, they also appear to significantly raise the hourly wages of likely unauthorized female workers. This unintended consequence may be the result of labor supply reductions that far exceed any cutbacks in the demand for the labor of likely unauthorized women -more likely to be employed in domestic services where the use of employment verification is highly improbable. In contrast, likely unauthorized men are more likely to be employed in sectors subject to employment verification, 
such as construction, than their female counterparts. As such, reductions in the demand for their labor may be equally as large as their labor supply cutbacks, thus lowering their employment but leaving their wages unaltered. None of these effects are observed among similarly aged and educated naturalized Hispanics.

At this juncture, it is worth noting a couple of potential shortcomings to our findings. First, one may be concerned about the possibility of migrant mobility across states. Previous studies, such as Lofstrom et al. (2011), explore the extent to which such mobility may be impacting the estimated impact of the enactment of a universal E-Verify mandate in Arizona by taking out of their control sample nearby states. They are unable to find any significant differences in their estimates. In our case, due to country-wide focus and the large number of states with E-Verify mandates, excluding nearby states to explore how the estimates change is not feasible. Nevertheless, we should point out that if migrant mobility were to be significant, our estimates would be providing a lower-bound of the employment and wage impacts of EVerify mandates.

Second, one might be worried about the possibility of misreporting or undercount of likely unauthorized immigrants following the enactment of an E-Verify mandate in the state. While this is certainly a possibility, it should not cause a problem unless those misreporting and undercounted are primarily holding a particular labor force status -perhaps they are mainly employed or unemployed, as opposed to being a randomly drawn sample of the likely unauthorized.

To conclude, we also explore how the enactment of employment verification systems may have affected the employment and hourly wages of natives. We find that the mandates, in particular universal mandates with a broader scope, raise the employment probability and/or 
hourly wages of native-born workers, hinting on the potential substitutability of relatively unskilled likely unauthorized immigrants and non-Hispanic natives.

\section{Summary and Policy Implications}

We gauge the impact that the increasing numbers of E-Verify mandates enacted at the state-level may be having on the employment and hourly wages of both likely unauthorized immigrant workers as well as on the native-born population. Because of the different scope of E-Verify programs, we distinguish between universal employment verification programs and programs targeting the public sector or companies contracting with the public sector.

Overall, we find that E-Verify mandates, in particular those with a universal scope, may have achieved their goal of reducing unauthorized employment and, in the process, helped increase native-born employment. Nevertheless, it is worth recognizing that these mandates may have unintended consequences. First, they may have raised the hourly wages of likely unauthorized women, making it more profitable for them to stay in the state where the mandate is approved. Second, they may have other unintended consequences worth exploring in future studies, such as the reshuffling of likely unauthorized workers from industries more likely to be screening workers into those with potential exemptions, or from formal to informal sectors (Lofstrom et al. 2011). Additionally, the enactment of E-Verify mandates, typically implemented on new hires, may have reduced job mobility among the likely unauthorized -an outcome that can be conducive to labor market discrimination. Hence, the apparent effectiveness needs to be weighed against the pull that higher wages may have among likely unauthorized female workers, the costly redistribution of likely unauthorized workers across industries or into the underground economy, and constrained job mobility inducing to discrimination and abuses. 
As such, the analysis underscores the need to further evaluate on a state-by-state basis the various impacts that employment verification systems may be having, not just on likely unauthorized workers, but also on natives. Ultimately, this information could prove highly valuable in the drafting of a much needed comprehensive immigration reform. 


\section{References}

Amuedo-Dorantes , Catalina and Cynthia Bansak. 2011. “The Impact of Amnesty on Labor Market Outcomes: A Panel Study Using the Legalized Population Survey” Industrial Relations, July 2011, v. 50, issue 3, pages 443-471.

Amuedo-Dorantes, Catalina and Cynthia Bansak. Forthcoming. "The Labor Market Impact of Mandated Employment Verification Systems” American Economic Review, May 2012.

Bansak, Cynthia and Steven Raphael. 2001. "Immigration Reform and the Earnings of Latino Workers: Do Employer Sanctions Cause Discrimination?”, Industrial and Labor Relations Review, 54(2): 275-95.

Bohn, Sarah, Magnus Lofstrom and Steven Raphael. 2010. “The Effect of State-Level Legislation Targeted towards Limiting the Employment of Undocumented Immigrants on the Internal Composition of State Populations: The Case of Arizona”, mimeo.

Gonzalez, Daniel. 2008. “Illegal Workers Manage to Skirt Arizona Employer-Sanctions Law Borrowed Identities, Cash Pay Fuel an Underground Economy”, Arizona Republic, November 30, 2008. At: www.azcentral.com/news/articles/2008/11/30/20081130underground1127.html

Immigration Works, USA. 2012. BOTTOM LINE: The Economic Consequences of State Immigration Law. Fact sheet, January. Available online at: http://www.immigrationworksusa.org/uploaded/file/IW\%20bottom\%20line.pdf

Lofstrom, Magnus, Sarah Bohn and Steven Raphael. 2011. Lessons from the 2007 Legal Arizona Workers Act. Public Policy Institute, California.

Meissner, Doris and Marc R. Rosenblum. 2009. The Next Generation of E-Verify: Getting Employment Verification Right. Washington, DC: Migration Policy Institute.

Passel, Jeffrey, and D’Vera Cohn. 2010. “U.S. Unauthorized Immigration Flows Are Down Sharply Since Mid-Decade.” Washington DC: Pew Hispanic Center.

Perotti, Rosanna. 1994. "Employer Sanctions and the Limits of Negotiation," The Annals of the American Academy of Political and Social Science, 534: 31-43.

Rosenblum, Marc R. 2011. "E-Verify: Strengths, Weaknesses, and Proposals for Reform.” Washington, DC: Migration Policy Institute.

Shore, Elena. “Alabama's HB 56 Forces Women to Make an Impossible Choice”, New American Media, March 23, 2012. Available at: http://newamericamedia.org/2012/03/alabamashb-56-forces-women-to-make-an-impossible-choice.php

U.S. Citizenship and Immigration Services. 2011. "E-Verify: History and Milestones" accessed at www.uscis.gov on 12/29/2011. 
U.S. Government Accountability Office (GAO). 2011. “Federal Agencies Have Taken Steps to Improve E-Verify, but Significant Challenges Remain”, GAO-11-146, Jan 18, 2011

Westat. 2009. "Findings of the E-Verify Program Evaluation”. Report submitted to Department of Homeland Security. Available at www.uscis.gov/USCIS/E-Verify/E-Verify/Final\%20EVerify\%20Report\%2012-16-09_2.pdf.

Wooldridge, Jeffrey M. 2008. Introductory Econometrics: A Modern Approach (4 ${ }^{\text {th }}$ ed.). Ohio: South-Western Cengage Learning. 
Table 1: Descriptive Statistics for Various Groups of Workers in Different States

\begin{tabular}{|c|c|c|c|c|c|c|}
\hline \multirow[t]{2}{*}{ Variables } & \multicolumn{2}{|c|}{$\begin{array}{c}\text { Workers in States without } \\
\text { E-Verify }\end{array}$} & \multicolumn{2}{|c|}{$\begin{array}{c}\text { Workers in States with } \\
\text { Universal E-Verify }\end{array}$} & \multicolumn{2}{|c|}{$\begin{array}{c}\text { Workers in States with } \\
\text { Public E-Verify }\end{array}$} \\
\hline & Obs. & Mean & Obs. & Mean & Obs. & Mean \\
\hline & \multicolumn{6}{|c|}{$\begin{array}{l}\text { Likely Unauthorized Immigrants } \\
\end{array}$} \\
\hline Employed & 189382 & 0.665 & 12262 & 0.652 & 55076 & 0.692 \\
\hline Log Real Hourly Wage & 29399 & 12.019 & 1844 & 11.733 & 8746 & 11.875 \\
\hline \multicolumn{7}{|l|}{ Industry (if working): } \\
\hline Agriculture & 125975 & 0.054 & 7993 & 0.020 & 38103 & 0.032 \\
\hline Construction & 125975 & 0.203 & 7993 & 0.317 & 38103 & 0.316 \\
\hline Private Households & 125975 & 0.024 & 7993 & 0.014 & 38103 & 0.020 \\
\hline Retail Trade & 125975 & 0.078 & 7993 & 0.061 & 38103 & 0.061 \\
\hline Administrative & 125975 & 0.115 & 7993 & 0.133 & 38103 & 0.107 \\
\hline Food Services & 125975 & 0.153 & 7993 & 0.126 & 38103 & 0.139 \\
\hline Male & 189382 & 0.545 & 12262 & 0.565 & 55076 & 0.581 \\
\hline White & 189382 & 0.944 & 12262 & 0.965 & 55076 & 0.949 \\
\hline Black & 189382 & 0.019 & 12262 & 0.007 & 55076 & 0.024 \\
\hline Age & 189382 & 31.179 & 12262 & 30.076 & 55076 & 30.255 \\
\hline Married & 189382 & 0.573 & 12262 & 0.553 & 55076 & 0.560 \\
\hline Number of Children & 189382 & 1.209 & 12262 & 1.208 & 55076 & 1.029 \\
\hline Less than High School & 189382 & 0.679 & 12262 & 0.677 & 55076 & 0.642 \\
\hline \multirow[t]{2}{*}{ High School } & 189382 & 0.321 & 12262 & 0.323 & 55076 & 0.358 \\
\hline & \multicolumn{6}{|c|}{ Naturalized Hispanics } \\
\hline Employed & 38267 & 0.731 & 1623 & 0.683 & 9592 & 0.746 \\
\hline Log Real Hourly Wage & 6367 & 14.626 & 256 & 13.438 & 1578 & 14.216 \\
\hline Industry (if working): & & & & & & \\
\hline Agriculture & 27988 & 0.024 & 1108 & 0.024 & 7151 & 0.017 \\
\hline Construction & 27988 & 0.129 & 1108 & 0.181 & 7151 & 0.156 \\
\hline Private Households & 27988 & 0.016 & 1108 & 0.005 & 7151 & 0.013 \\
\hline Retail Trade & 27988 & 0.110 & 1108 & 0.106 & 7151 & 0.114 \\
\hline Administrative & 27988 & 0.078 & 1108 & 0.039 & 7151 & 0.067 \\
\hline Food Services & 27988 & 0.100 & 1108 & 0.084 & 7151 & 0.093 \\
\hline Male & 38267 & 0.504 & 1623 & 0.484 & 9592 & 0.519 \\
\hline White & 38267 & 0.938 & 1623 & 0.959 & 9592 & 0.959 \\
\hline Black & 38267 & 0.029 & 1623 & 0.014 & 9592 & 0.017 \\
\hline Age & 38267 & 34.940 & 1623 & 33.268 & 9592 & 33.915 \\
\hline Married & 38267 & 0.670 & 1623 & 0.625 & 9592 & 0.652 \\
\hline Number of Children & 38267 & 1.444 & 1623 & 1.385 & 9592 & 1.311 \\
\hline Less than High School & 38267 & 0.497 & 1623 & 0.494 & 9592 & 0.439 \\
\hline \multirow[t]{2}{*}{ High School } & 38267 & 0.503 & 1623 & 0.506 & 9592 & 0.561 \\
\hline & \multicolumn{6}{|c|}{ Non-Hispanic Natives } \\
\hline Employed & 1185318 & 0.609 & 98421 & 0.564 & 449684 & 0.613 \\
\hline Log Real Hourly Wage & 161913 & 14.597 & 12323 & 13.570 & 61616 & 14.052 \\
\hline \multicolumn{7}{|l|}{ Industry (if working): } \\
\hline Agriculture & 721737 & 0.019 & 55492 & 0.011 & 275860 & 0.016 \\
\hline Construction & 721737 & 0.112 & 55492 & 0.118 & 275860 & 0.114 \\
\hline Private Households & 721737 & 0.006 & 55492 & 0.006 & 275860 & 0.006 \\
\hline Retail Trade & 721737 & 0.169 & 55492 & 0.156 & 275860 & 0.163 \\
\hline Administrative & 721737 & 0.042 & 55492 & 0.042 & 275860 & 0.046 \\
\hline Food Services & 721737 & 0.107 & 55492 & 0.101 & 275860 & 0.115 \\
\hline Male & 1185318 & 0.536 & 98421 & 0.525 & 449684 & 0.528 \\
\hline White & 1185318 & 0.807 & 98421 & 0.697 & 449684 & 0.760 \\
\hline Black & 1185318 & 0.121 & 98421 & 0.266 & 449684 & 0.199 \\
\hline Age & 1185318 & 28.573 & 98421 & 29.237 & 449684 & 28.596 \\
\hline Married & 1185318 & 0.328 & 98421 & 0.361 & 449684 & 0.342 \\
\hline Number of Children & 1185318 & 0.652 & 98421 & 0.691 & 449684 & 0.671 \\
\hline Less than High School & 1185318 & 0.346 & 98421 & 0.382 & 449684 & 0.360 \\
\hline High School & 1185318 & 0.654 & 98421 & 0.618 & 449684 & 0.640 \\
\hline
\end{tabular}


Table 2: Employment Impacts of the Enactment of Universal and Public Sector Mandates

\begin{tabular}{lccc}
\hline & All & Men & Women \\
\hline & Panel A: Employment Likelihood of Likely Unauthorized Immigrants & \\
\hline Universal Mandate & $-0.046^{* * *}$ & $-0.055^{* * *}$ & $-0.024^{* *}$ \\
& $(0.007)$ & $(0.010)$ & $(0.015)$ \\
Public Sector Mandate & $-0.020^{* *}$ & $-0.026^{* * *}$ & -0.014 \\
& $(0.011)$ & $(0.008)$ & $(0.020)$ \\
Observations & 256,720 & 142,180 & 114,540 \\
R-squared & 0.215 & 0.074 & 0.091 \\
\hline & Panel B: Employment Likelihood of Naturalized Hispanics & \\
\hline Universal Mandate & 0.020 & 0.045 & -0.016 \\
& $(0.027)$ & $(0.055)$ & $(0.102)$ \\
Public Sector Mandate & -0.021 & -0.002 & -0.029 \\
& $(0.024)$ & $(0.036)$ & $(0.031)$ \\
Observations & 49,482 & 25,061 & 24,421 \\
R-squared & 0.129 & 0.119 & 0.070 \\
\hline & $(0.002)$ & $0.019^{* *}$ & \\
\hline Universal Mandate & 0.006 & $(0.010)$ & $0.019 * *$ \\
& $(0.005)$ & $0.015^{* *}$ & $-0.009)$ \\
Public Sector Mandate & $1,957,420$ & $(0.007)$ & $(0.004)$ \\
Observations & 0.183 & $1,037,799$ & 919,621 \\
R-squared & 0.238 & 0.131 \\
\hline
\end{tabular}

Notes: ***Significant at the 1 percent level or better, ${ }^{* *}$ significant at 5 percent level or better and *significant at the 10 percent level or better using one-tail tests. The regressions include information on gender (when appropriate), age, race, marital status, number of children and educational attainment. Additionally, all regressions include a constant term as well as state fixed-effects, time (year, interview month) fixed-effects, and state-level time trends. Wage regressions also include industry dummies. Standard errors are clustered at the state level. 
Table 3: Wage Impacts of the Enactment of Universal and Public Sector Mandates

\begin{tabular}{lccc}
\hline & All & Men & Women \\
\hline & Panel A: Log Real Hourly Wages of Likely Unauthorized Immigrants & $0.169 * * *$ \\
Universal Mandate & $0.064 * *$ & 0.020 & $(0.028)$ \\
& $(0.034)$ & $(0.048)$ & -0.019 \\
Public Sector Mandate & -0.017 & -0.017 & $(0.038)$ \\
& $(0.019)$ & $(0.016)$ & 12,234 \\
Observations & 39,974 & 27,740 & 0.144 \\
R-squared & 0.210 & 0.186 & $(0.084)$ \\
\hline & Panel B: Log Real Hourly Wages of Naturalized Hispanics & 0.003 \\
\hline Universal Mandate & 0.098 & 0.072 & $(0.053)$ \\
Public Sector Mandate & $(0.081)$ & $(0.088)$ & 3,483 \\
Observations & -0.006 & 0.006 & $(0.037)$ \\
R-squared & $(0.034)$ & 4,707 & 0.186 \\
\hline & 8,190 & 0.238 & \\
\hline Universal Mandate & 0.236 & 0.103 \\
Public Sector Mandate & Panel C: Log Real Hourly Wages of Non-Hispanic Natives & \\
Observations & 0.018 & $0.029 *$ & $(0.022)$ \\
R-squared & $(0.015)$ & $0.019 * * *$ & $(0.007)$ \\
\hline
\end{tabular}

Notes: $* * *$ Significant at the 1 percent level or better, **significant at 5 percent level or better and *significant at the 10 percent level or better using one-tail tests. The regressions include information on gender (when appropriate), age, race, marital status, number of children and educational attainment. Additionally, all regressions include a constant term as well as state fixed-effects, time (year, interview month) fixed-effects, and state-level time trends. Finally, these wage regressions also include industry dummies. Standard errors are clustered at the state level. 
Appendix Table

Enactment Dates for E-Verify Mandates, 2004-2011

\begin{tabular}{lll}
\hline State & Enactment Date & Scope of the Mandate \\
\hline AL & Jun-11 & Universal \\
AZ & Jul-07 & Universal \\
CO & Jun-06 & Public Sector \\
FL & Jan-11 & Public Sector \\
GA & Apr-06 & Public Sector \\
ID & Dec-06 & Public Sector \\
IN & May-11 & Public Sector \\
LA & Jul-11 & Public Sector \\
MN & Jan-08 & Public Sector \\
MS & Mar-08 & Universal \\
MO & Jul-08 & Public Sector \\
NE & Apr-09 & Public Sector \\
NC & Aug-06 & Public Sector first, Universal after Oct. 2011 \\
OK & May-07 & Public Sector \\
SC & Jun-08 & Public Sector first, Universal after January 2012 \\
TN & Jun-11 & Universal \\
UT & Mar-08 & Public Sector first, Universal after March 2010 \\
VA & Apr-10 & Public Sector \\
\hline
\end{tabular}

